\title{
Late-Quaternary Paleoclimatic Data and Climate Models
}

\section{by Thompson Webb III, F. Alayne Street-Perrott and John E. Kutzbach}

Some very important advances in our understanding of climate - past, present and future - are coming from computer models of atmospheric circulation, reviewed briefly in this article. One task for Quaternarists is to check these models with paleoclimatic data from other studies involving, for example, pollen, marine plankton and lake levels. The authors summarize some areas of agreement and some findings that are in diseord. (Ed.)

Modelling Atmospheric Circulation

General circulation models of the atmosphere are major tools for estimating the patterns of future climates that may result from increased concentrations of carbon dioxide (Manabe and Wetherald, 1975; Schlesinger and Mitchell, in MacCracken and Luther, 1985) or from increased smoke and dust after major nuclear or volcanic explosions (Covey et al., 1985). Such changes in atmospheric composition and turbidity can cause significant variations in the earth's radiation balance. The general circulation models not only estimate the changes in radiation but also translate them into different patterns of temperature, moisture, and atmospheric circulation. Tests of the model results are needed, however, before the simulated patterns should be considered accurate predictions of future climates.

Instrumental records of climate provide only limited tests of the accuracy of these models, but records of past climates can allow a broad testing of the capabilities of the climate models over a range of known changes in orbitally induced radiation (Webb and Wigley, in MacCracken and Luther, 1985). To be useful in such testing, the data should cover large variations in climate, be accurately dated, have broad geographic coverage, and provide quantitative estimates of climatic variables. The general causes of the past changes in climate should also be known. 
Paleoclimatic data from pollen, marine plankton, and lake levels for the past 18,000 years fulfill these criteria. During this period, the climatic changes record the switch from full-glacial to interglacial conditions. The stratigraphic levels involved have many radiocarbon dates, which yield an accuracy between cores of \pm 300 years (Webb, 1982). Sets combining these three types of data are nearly global in coverage (Street-Perrott and Harrison, 1985; Webb, 1985), and methods exist for transforming each type into estimates of past climatic variables (Kutzbach, 1980; Imbrie and Kipp, 1971; Bartiein et al., 1984).

\section{Boundary Conditions}

In addition, the major atmospheric boundary conditions for the climate changes during this period are well known (Berger, 1978a, b; CLIMAP, 1981). These conditions include the seasonal and latitudinal changes in solar radiation at the top of the atmosphere (resulting from modifications in the earth's orbit about the sun), as well as variations in seasurface temperatures (CLIMAP, 1981), major ice sheets (Denton and Hughes, 1981), and atmospheric composition and turbidity (Lorius et al., 1984). Over the past 18,000 years, this set of boundary conditions has altered significantly at 3,000-year intervals (Fig. l), providing a framework for numerical experimentation with general circulation models. For selected dates in the past $(18,000$, 15,000 years ...), these models simulate "snapshots" of the climate in equilibrium with the boundary conditions (Kutzbach, 1981; Kutzbach and Guetter, 1986).

This kind of study follows from the work of Williams and others, (1974), Gates (1976), and Manabe and Hahn (1977), who used a specific set of surface boundary conditions to model the climate of $18,000 \mathrm{yBP}$. It also builds on the zonal and global-average models of Suarez and Held (1976) and Imbrie and Imbrie (1980) that showed the possible role of orbital parameter variations in changing the climate.

An examination of the variations in the earth's orbit shows that over the past 18,000 years the time of perihelion has shifted from January to July (at about $10,000 \mathrm{yBP}$ ) and then back to January, the current situation. This paralleled a modification in tilt, from $23.5^{\circ}$ at 18,000 yBP to $24.5^{\circ}$ at about $10,000 \mathrm{yBP}$ and then back to the present value of $23.5^{\circ}$. These two changes combined to produce increased seasonality in northern hemisphere climates between 12,000 and 9,000 years ago. Compared to modern conditions, solar radiation at the top of the atmosphere at 10,000 yBP was increased by about $8 \%$ in June through August and decreased by about $8 \%$ in December through February over the northern hemisphere. Figure 1 shows these and other changes in the last 18,000 years, with reference to seven sets of simulation experiments (arrows) with the U.S. National Center of Atmospheric Research Community Climate vodel.

Experiments with both low- and high-resolution circulation models show that the increased seasonality at 9,000 yBP resulted in continental interiors that were warmer in summer and cooler in winter than they are today. This intensified the summer monsoon circulation of Africa and southern Asia, because ocean temperatures during these seasons were much the same as today (Kutzbach, 1981; Kutzbach and Otto-Bliesner, 1982; Kutzbach and Guetter, 1986; Fairbridge, 1986). Evidence from latitudes $9^{\circ} \mathrm{N}$ to $27^{\circ} \mathrm{N}$ show that the water levels in lakes were higher then and that the increase and decrease in these levels generally paralleled the changes in precipitation minus evaporation, simulated by the general circulation model for the land areas in this latitudinal belt (Kutzbach and Street-Perrott, 1985).

The model results have also provided new insights about the variations in past climates. They have produced, for example, estimates for past changes in circulation that can only be guessed at from paleoclimatic data. The models

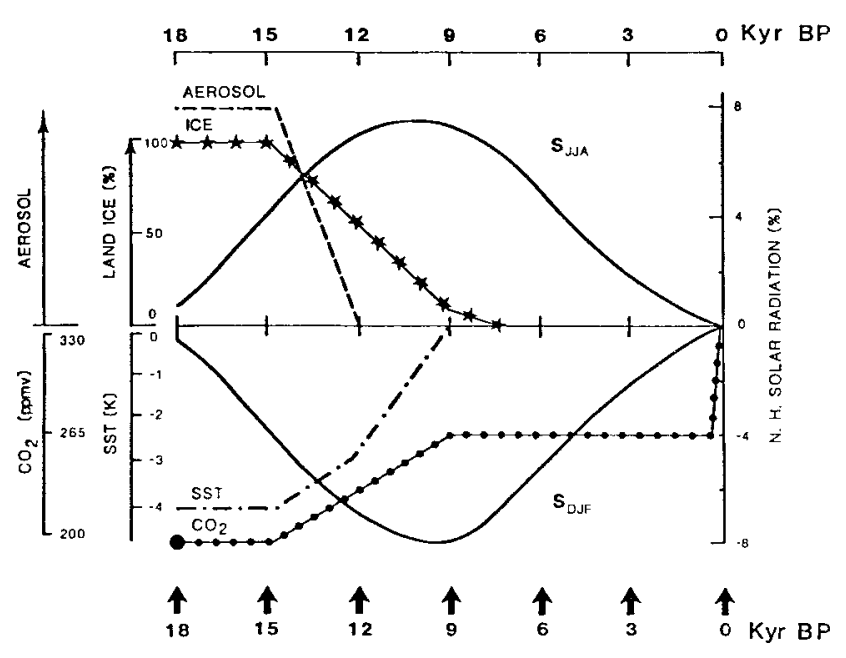

Figure 1: Schematic diagram from Kutzbach and Street-Perrott (1985) of major changes since 18,000 $y B P$ in (1) external forcing (Northern Hemisphere solar radiation in June-August ( $\left.S_{J J A}\right)$ and December-February $\left(S_{D J F}\right)$, as percentage difference from present); (2) land ICE as percentage of 18,000 $y B P$ ice volume; (3) global mean annual sea-surface temperature (SST) in degrees $K$ (including calculated surface temperature over sea ice) as departure from present; (4) excess glacial-age AEROSOL, arbitrary scale; and (5) atmospheric $\mathrm{CO}_{2}$ concentration in ppmv.

illustrate how the contrast between land and ocean amplifies the orbitally driven changes in seasonal radiation by varying the intensity of the monsoons. Such variations provide a possible mechanism by which relatively small changes in radiation can have a large influence on global climates, throughout all of the geological record (Olson, 1986; Berger et al., 1984) and particularly so in the tropics. Studies are still being pursued on the effect of changes in tropical climates on mid- to high-latitude climates and of the orbital variations on the growth and retreat of ice sheets (Ruddiman and McIntyre, 1981; Ritchie et al., 1983; Heusser et al., 1985).

\section{Checking the Models Against the Data}

Comparisons between model results and paleoclimatic data in mid- to high-latitudes have also been made. For 18,000 $\mathrm{yBP}$, these show that the Laurentide jee sheet at full height may have acted to split the flow of the jet stream across the continent with a branch to the north over Alaska and a second branch dipping south to flow across the southwest (Kutzbach and Wright, 1985). This result is compatible with the geographic patterns of lake level and vegetation changes inferred from the data. More recent work that compares model results with pollen data (Webb et al, and Barnosky et al., in Ruddiman and Wright, in press) involves detailed regional comparisons between the predicted temperature and moisture conditions.

Some comparisons between the model results and the data reveal areas of discordance. For example, the model showed moisture increases in the northern tropics at 15,000 and 12,000 years ago when the data indicated relatively dry conditions (Kutzbach and Street-Perrott, 1985). Work is now in progress to study these areas and times of discordance and to use them to suggest improvements to the data, to the model, to the boundary conditions used and to the methods for comparing the data to the model resuits. The work is iterative and will not only provide critical tests of 
the models but will also yield major insights about past climates and thus increase general understanding of how the climate system operates.

Acknowledgments: Research support came from U.S. National Science Foundation grants to COHMAP (Cooperative Holocene Mapping Projects) and a U.S. Department of Energy grant (DE-FG02-85ER60304) from the Carbon Dioxide Research Office.

INQUA '87. Special Session 21: Holocene Climatic Change (Data/Model Comparisons). Organizers: T. Webb III (U.S.A.) and F.A. Street-Perrott (U.K.).

Dr. T. Webb III is a Professor of Geological Sciences at Brown University in Providence (Rhode Island 02912-1846, U.S.A.). A palynologist and paleoclimatologist, he holds degrees in botany and meteorology and has also trained in paleoecology. He is President of the INQUA Subcommission on the Holocene for North America and Greenland.

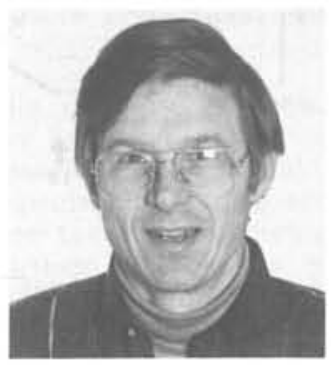

Dr. F.A. Street-Perrott is a Lecturer at the School of Geography, Oxford University (Oxford OXI 3TB, U.K.). She is a Quaternary stratigrapher who studies fluctuations in tropical lake levels and is also President of INQUA's Paleoclimate Commission.

Dr. J.E. Kutzbach, is a Professor of Meteorology and Environmental Studies, and Director of the Center for Climatic Research, at the University of Wisconsin (Madison, Wisconsin 53706, U.S.A.). With a background in electrical engineering and meteorology, he is now a climatologist and climate modeller.
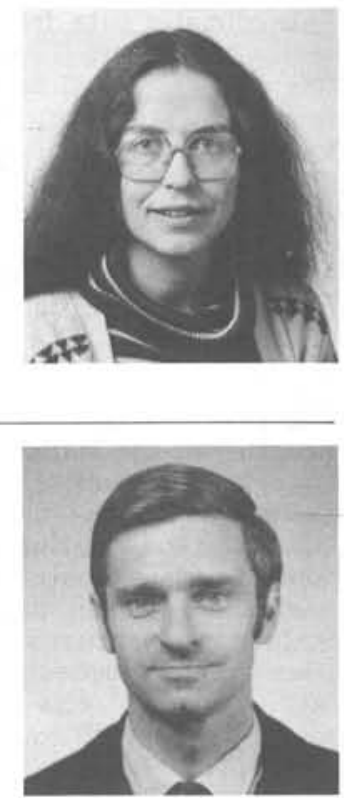

\section{References}

Bartlein, P.J., Webb, T. III and Fleri, E.C., 1984. Holocene climatic change in the northern Midwest, pollen-derived estimates. Quaternary Research, v. 22 , no. 3 , p. $361-374$.

Berger, A.L., 1978a. Long-term variations of daily insolation and Quaternary climatic changes. Journal of Atmospheric Science, v. 35, no. 12 , p. 2362- 2367 .

Berger, A.L., 1978b. Long-term variations of ealoric insolation resulting from the earth's orbital elements. Quaternary Research, v. 9 , no. 1 , p. 139-167.

Berger, A., Imbrie, J., Hays, J., Kukla, G. and Saltzman, B. (eds.), 1984. Milankoviteh and Climate. D. Reidel Publishing Company, Dordrecht, $895 \mathrm{p}, 2$ vols.

CLIMAP Project Members, A. MeIntyre (compiler), 1981. Seasonal reconstructions of the earth's surface at the last glacial maximum. Geological Society of America Map and Chart Series, v. MC-36, 18p.

Covey, C., Thompson, S.L. and Schneider, S.H., 1985. "Nuclear winter"; a diagnosis of atmospheric general circulation model simulations. Journal of Geophysical Research, v. 90, no. D3, p. 5615-5628.

Denton, G.H. and Hughes, T.J. (eds.), 1981. The Last Great Ice Sheets. Wiley Intersciences, New York, 484p.

Fairbridge, R.W., 1986. Monsoons and Paleomonsoons. Episodes, v. 9, p. 143-149.

Gates, W.L., 1976. The numerical simulation of ice-age climate with a global circulation model. Journal of Atmospheric Science, v. 33, p. $1844-1873$.

Heusser, C.J., Heusser, L.E. and Peteet, D.M., 1985. Late-Quaternary climatic change on the American North Pacific Coast. Nature, v. 315 no. 6019 , p. 485-487.

Imbrie, J. and Imbrie, J.Z., 1980. Modeling the climatic response to orbital variations. Seience, v. 207, no. 4434, p. 943-953.

Imbrie, J. and Kipp, N.G., 1971. A new micropaleontological method for quantitative paleoclimatology: application to a Late Pleistocene Caribbean core. In: K. Turekian (ed.), The Late Cenozoic Glacial Ages. Yale University Press, New Haven, p. 71-181.

Kutzbach, J.E., 1980. Estimates of past climate at paleolake Chad, North Africa, based on a hydrological and energy-balance model. Quaternary Research, v. 14, no. 2, p. 210-223.

Kutzbach, J.E., 1981. Monsoon climate of the early Holocene; climate experiment with the earth's orbital parameters for 9,000 years ago. Science, v. 214, no. 4516, p. 59-61.

Kutzbach, J.E. and Guetter, P.J., 1986. The influence of changing orbital parameters and surface boundary conditions on climate simulations for the past 18,000 years. Journal of Atmospheric Science, v. 43 , p. $1726-1759$.

Kutzbach, J.E. and Otto-Bliesner, B.L., 1982. The sensitivity of the African-Asian monsoonal climate to orbital parameter changes for
9,000 years B.P. in a low-resolution general eirculation model. Journal of Atmospheric Science, v. 39, no. 6, p. 1177-1188.

Kutzbach, J.E. and Street-Perrott, F.A., 1985. Nilankovitch foreing of fluctuations in the level of tropical lakes from 18 to 0 kyr B.P. Nature, v. 317 , no. 6033 , p. $130-134$.

Kutzbach, J.E. and Wright, H.E., Jr., 1985. Simulation of the climate of 18,000 years BP: Results from the North American/ North Atlantic/ European sector and comparison with the geologic record of North America. Quaternary Science Reviews, 4, p. 147-188.

Lorius, C., Raynaud, D., Petit, J.R., Jouzel, J. and Merlivat, L., 1984. Late-glacial maximum-Holocene atmospheric and ice-thickness changes from Antaretic ice-core studies. Annals of Glaciology, v. 5, p. 88-94.

Manabe, S. and Wetherald, R.T., 1975. The effects of doubling the $\mathrm{CO}_{2}$ concentration on the climate of a general circulation model. Journal of Atmospheric Science, v. 32, no. 1, p. 3-15.

Manabe, S. and Hahn, D.G., 1977. Simulation of the tropical climate of an ice age. Journal of Geophysical Research, v. 82 , no. 27, p. 38893911 .

MacCracken, M.C. and Luther, F.M. (eds.), 1985. Projecting the climatic effects of increasing carbon dioxide, DOE/ ER-0237. U.S. Department of Energy, Washington, D.C., p. 81-147.

Olson, P.E., 1986. A 40-million-year lake record of early Mesozoic orbital climatic forcing. Science, v. 234 , no. 4778 , p. 842-848.

Ritchie, J.C., Cwynar, L.C. and Spear, R.W., 1983. Evidence from northwest Canada for an early Holocene Milankovitch thermal maximum. Nature, v. 305 , no. 5930 , p. $126-128$.

Ruddiman, W.F. and MeIntyre, A., 1981. The North Atlantic Ocean during the last deglaciation. Palaeogeography, Palaeoclimatology, Palaeoecology, v. 35 , no. 2-4, p. 145-214.

Ruddiman, W.F. and Wright, H.E. Jr. (eds.), in press. North America and adjacent oceans during the last deglaciation. The Geology of North America, v. K-3, Geological Society of America, Boulder, Colorado.

Street-Perrott, F.A. and Harrison, S.P., 1985. Lake-levels and climate reconstruction. In: Hecht, A.D. (ed.), Paleoclimate analysis and modeling. John Wiley and Sons, New York, p. 291-340.

Suarez, N.J. and Held, I.M., 1976. Modelling climatic response to orbital parameter variations. Nature, v. 263, no. 5572, p. 46-47.

Webb, T. III, 1982, Temporal resolution in Holocene pollen data. In: Mamet, B, and Copeland, M.J. (eds.), Third North American Paleontological Convention, Proceedings. 3, p. 569-572.

Webb, T. III, 1985. Holocene palynology and climate. In: Hecht, A.D. (ed.), Paleoclimate Analysis and Modeling. John Wiley and Sons, New York, p. 163-195.

Williams, J., Barry, R.G. and Washington, W.M., 1974. Simulation of the atmospheric circulation using the NCAR global circulation model with ice age boundary conditions. Journal of Applied Meteorology, v. 13 , no. 3 , p. $305-317$. 